\title{
Pharmaceutical hit of anti type 2 Diabetes mellitus on the phenolic extract of Malaka (Phyllanthus emblica L.) flesh
}

\author{
Musri Musman $^{1 *}$ D, Mauli Zakia ${ }^{1 *}$, Ratu Fazlia Inda Rahmayani ${ }^{1}$, Erlidawati Erlidawati ${ }^{1}$ and Safrida Safrida ${ }^{2}$
}

\begin{abstract}
Background: Ethnobotany knowledge in a community has shaped local wisdom in utilizing plants to treat diseases, such as the use of Malaka (Phyllanthus emblica) flesh to treat type 2 diabetes. This study presented evidence that the phenolic extract of the Malaka flesh could reduce blood sugar levels in the diabetic induced rats.

Methods: The phenolic extract of the P. emblica was administrated to the glucose-induced rats of the Wistar strain Rattus norvegicus for 14 days of treatment where the Metformin was used as a positive control. The data generated were analyzed by the two-way ANOVA Software related to the blood glucose level and by SAS Software related to the histopathological studies at a significant $95 \%$ confidence.

Results: The phenolic extract with concentrations of 100 and $200 \mathrm{mg} / \mathrm{kg}$ body weight could reduce blood glucose levels in diabetic rats. The post hoc Dunnet test showed that the administration of the extract to the rats with a concentration of $100 \mathrm{mg} / \mathrm{kg}$ body weight demonstrated a very significant decrease in blood glucose levels and repaired damaged cells better than administering the extract at a concentration of $200 \mathrm{mg} / \mathrm{kg}$ weight body.
\end{abstract}

Conclusion: The evidence indicated that the phenolic extract of the Malaka flesh can be utilized as anti type 2 Diabetes mellitus without damaging other organs.

Keywords: Phyllanthus emblica, Malaka, Antioxidant, Diabetes mellitus, Phenolics

\section{Introduction}

Diabetes mellitus is characterized by a condition of metabolic disorders that causes an increase in the level of blood glucose (hyperglycemia) beyond the normal limits [1]. For non-diabetics, normal blood glucose levels in the human are a range of 72 to $99 \mathrm{mg} / \mathrm{dL}$ (before meal) and equal to $140 \mathrm{mg} / \mathrm{dL}$ ( $2 \mathrm{~h}$ after meal). For diabetics, the blood glucose level may have ranged more or less $100 \mathrm{mg} / \mathrm{dL}$ (before meal) and less $180 \mathrm{mg} / \mathrm{dL}(2 \mathrm{~h}$ after meal) [2,3]. The prevalence of diabetes in the world in 2017 reached 425 million people and is estimated to reach 629 million people by 2045 . In Indonesia, the prevalence of diabetes reached 10.28 million people in 2017, and is estimated to reach 16.65 million people by 2045 [4]. Diabetics in the Aceh region in 2017

\footnotetext{
* Correspondence: musrimusman@unsyiah.ac.id

${ }^{1}$ Department of Chemistry Education, Teacher Training and Education Faculty, Syiah Kuala University, Darussalam-Banda, Aceh 23111, Indonesia Full list of author information is available at the end of the article
}

reached 500 thousand people (9.8\%) from the population of five million people. The figure of $9.8 \%$ was above the national figure which was merely $5.8 \%$ [5].

Management of Diabetes mellitus generally uses synthetic and natural antidiabetic drugs [6]. For synthetic drugs, compounds are generally classified as sulphonylureas, biguanides, meglitinides, thiazolidinediones, and $\alpha$-glucosidase inhibitors $[7,8]$. However, the administration of synthetic antidiabetic drugs increases complications in the heart, kidneys, and nerves [1,9]. The use of ingredients for the treatment of diabetes has been studied and has shown promising results by suppressing adverse side effects for other organs. The success of utilizing natural ingredients in the prevention of diabetes has been proven both in traditional Chinese medicine [10] and Ayurvedic medicine in India society [11, 12]. A group of natural components that can provide antidiabetic therapy comes from phenolic compounds. Phenolic compounds are generally classified as phenolic acids, 
flavonoids, tannins, coumarins, lignans, quinones, stilbenes, curcuminoids, and others [13]. Among them, flavonoids receive attention in curing diabetes because of their high antioxidant activity [14].

Malaka fruit (fruit name of Achehnese or Phyllanthus emblica L.) has been used by diabetics who are residents of the village of Lamtamot, Lembah Seulawah sub-district. They stated that their blood glucose levels decrease by consuming Malaka fruits every day by five after each meal. The testimony was in line with the statement of the previous researcher explained that the Malaka fruit has antidiabetic power $[15,16]$. This power is generated by the phenolic components $[17,18]$. The Malaka fruit is one of the most widely used fruits as traditional medication with many benefits [19-21]. Generally, to obtain phenolic compounds from plant samples, extraction is carried out with different solvent polarities. This difference goals to obtain a variety of phenolic components with varying antidiabetic abilities. Previous studies informed that the extraction of Malaka fruit used polar solvents such as water and/or ethanol. However, research to utilize an extract from the Malaka flesh using semi-polar solvent has never been done [16, 22-24]. This research is a basic study of an extract obtained from semi-polar solvents from the Malaka flesh as a type 2 anti Diabetes mellitus candidate.

\section{Materials and methods}

\section{Venue and time}

This research was conducted at the Chemical Laboratory of Faculty of Teacher Training and Education, and Pharmacological Laboratory of Veterinary Faculty of Syiah Kuala University in 2017/2018.

\section{Instruments}

The instruments used are analytical scales, blenders, knives, 40 mesh sieve, rotary evaporator, petri dishes, spatulas, beakers, measuring cylinders, volume pipettes, stirring rods, funnels, measuring flasks, reagent bottles, test tubes, spirit burner, tripod, gauze wire, separating funnel, clamps, stativ, Spectronic $20 \mathrm{D}^{+}$Spectrophotometer, injection device, and multicheck Nesco.

\section{Materials}

The ingredients used were powdered Malaka flesh, ethanol $96 \%$, filter papers, aquadest, $\mathrm{NaOH} 0.1 \mathrm{M}, \mathrm{NaOH}$ $1 \%, \mathrm{HCl} 2 \mathrm{~N}, \mathrm{FeCl}_{3} 1 \mathrm{M}$, ammonia $10 \%$, gelatin $1 \%$, formalin $10 \%$, Mayer's reagent, Hager's reagent, Wagner's reagent, Burchard's reagent, Dragendorff's reagent, chloroform, tap water, hot water, anhydrous acetic acid p.a, sulfuric acid p.a, n-hexane p.a, dichloromethane p.a, ethyl acetate p.a, methanol p.a, DPPH, ascorbic acid, glucose monohydrate p.a., metformin, strip test Nesco, and feeds 4 .

\section{Sample preparation}

Malaka fruits were obtained from the village of Lamtamot $\left(5.3779^{\circ} \mathrm{N}, 95.6984^{\circ} \mathrm{E}\right)$, sub-district of Seulawah Valley, Aceh Besar District. The sample was washed with clean water and drained to dry. After drying, the flesh and seed were separated. The meat obtained is cut into small pieces and then dried without being exposed to sunlight. The dried Malaka flesh was blended to get a 40 mesh Malaka flesh powder.

\section{Maceration}

The Malaka flesh powder was weighed as much as $300 \mathrm{~g}$, then soaked with $1.5 \mathrm{l}$ of ethanol $96 \%$ for $72 \mathrm{~h}$. The ethanolic extract of the Malaka flesh powder was filtered with filter paper \# 1 Whatman, then the filtrate was concentrated using a rotary evaporator at $45^{\circ} \mathrm{C}$. The condensed extract of the Malaka flesh was dried and weighed to get $37.8 \mathrm{~g}$ solid extracts.

\section{Sample separation}

The ethanolic condensed extract of Malaka flesh as much as $30 \mathrm{~g}$ was dissolved in $25 \mathrm{~mL}$ of ethyl acetate p.a. solvent, and then the solution was poured into a $100 \mathrm{~mL}$ separating funnel. Solvent of n-hexane p.a. as much as $25 \mathrm{~mL}$ in volume was added to the funnel, then shaken the funnel gently and let stand until the two layers to separate completely. The n-hexane layer was used up, and left the ethyl acetate layer in the separating funnel. Another $25 \mathrm{~mL}$ of $\mathrm{n}$-hexane p.a. solvent was added into the separating funnel containing the ethyl acetate layer, shaken and let stand until there was a separation of the two layers. The nhexane layer was picked up, and the ethyl acetate layer remained in the separating funnel. The nhexane layer obtained was collected in $50 \mathrm{~mL}$ Erlenmeyer flask. The separation of the extract components was repeated by applying the same procedure where the solvent $n$-hexane p.a. replaced with dichloromethane solvent p.a. The remaining layer in the separating funnel after the separation using the dichloromethane solvent was the ethyl acetate layer. The fractions obtained were concentrated with the rotary evaporator at $45{ }^{\circ} \mathrm{C}$. The fractions were tested for phytochemical screening to determine the secondary metabolite contents.

\section{Phytochemical evaluation}

Phytochemical screening for the fraction obtained was based on the procedure described by Tiwari et al. which includes testing for triterpenoids, alkaloids, saponins, tannins, flavonoids, and phenols [25]. 


\section{Total Phenolics content measurement}

Measurement of total phenol content in the ethyl acetate extract was conducted by modifying the FolinCiocalteu's procedure revealed by Siddiqui et al. [26]. Calibration curves were made using gallic acid with variations in concentrations of $0.005,0.010,0.025$, 0.050 , and $0.100 \mathrm{mg} / \mathrm{mL}$. Then, a solution of the ethyl acetate extract with a concentration of $0.1 \mathrm{mg} / \mathrm{mL}$ was made. Furthermore, the extract solution was taken as much as one milliliter and put into $10 \mathrm{~mL}$ volumetric flask, $500 \mu \mathrm{L}$ of Folin Ciocalteu reagent was added, then shaken until homogeneous for a minute. In the seventh minute, four $\mathrm{mL}$ of $7.5 \%(\mathrm{w} / \mathrm{v}) \mathrm{Na}_{2} \mathrm{CO}_{3}$ was added to the solution of the ethyl acetate extract and the Folin Ciocalteu reagent in the measuring flask, shaken for a minute and added distilled water to the volume limit of the flask, and shaken again until homogeneous. Then the measurement was performed with a spectrophotometer at a wavelength of $794 \mathrm{~nm}$, where the wavelength was obtained when scanning wavelength. The results of this measurement are expressed as weight equivalent to gallic acid per sample weight.

\section{Determination of antioxidant activity}

The antioxidant testing procedure was modified from the DPPH method presented by Molyneux [27]. A total of $0.0012 \mathrm{~g}$ of crystalline DPPH was dissolved to $25 \mathrm{~mL}$ methanol p.a. in order to get $0.1 \mathrm{mM}$ of DPPH as a control. The extract solution of the ethyl acetate fraction at dose of $1000 \mathrm{ppm}$ was prepared by dissolving $0.025 \mathrm{~g}$ of the ethyl acetate fraction in $25 \mathrm{~mL}$ of methanol p.a. Next step, the concentrations of 2, 4, 6, and $8 \mathrm{ppm}$ were prepared to the extract solution. A three milliliter of each concentration of the extract solution was combined to a milliliter of $0.1 \mathrm{mM}$ of $\mathrm{DPPH}$ in cuvette to prepare a testing solution. The testing solution was stabilized and retained standup at chamber temperature for a half hour. The same working procedure was repeated to the vitamin $\mathrm{C}$ solution as the standard of antioxidant at a concentration of 2 , 4, 6 and $8 \mathrm{ppm}$. The absorbance of the control solution, the testing solution, and the standard solution was measured at $517 \mathrm{~nm}$ using a Spectronic 20D ${ }^{+}$ spectrophotometer. The obtained absorbance value of the solutions was converted to the percent of inhibition, and further were confined to the $\mathrm{IC}_{50}$.

\section{In vivo toxicity assay}

A healthy and mature (200-250 g) Rattus norvegicus were separated into four groups consisting of three rats in each group. Rats were placed in each ventilated enclosure and got sunlight. The rats were given food in the form of pellets and drinks of distilled water. Adaptation of all groups of rats were done for one week [28]. All the rats in the group were coded and weighed. A blood glucose level was examined on the seventh day. The blood glucose level obtained was expressed as a pre-treatment blood. The rats were orally given a $50 \%$ glucose monohydrate solution on the eighth and eleventh days with one $\mathrm{mL}$ per rat. After one week given the $50 \%$ glucose solution, the rats were checked their blood glucose level and marked as a diabetic blood when the blood glucose level was above $180 \mathrm{mg} / \mathrm{dL}$. The experimental rats were designed into P0 group stood for negative control (the group only was given pellet plus tap water), P1 group stood for positive control (the group was given the metformin at a concentration of $65 \mathrm{mg} / \mathrm{kg}$ body weight), and P2 and P3 groups were given the extracts of ethyl acetate of the Malaka powder with concentrations of 100 and $200 \mathrm{mg} / \mathrm{kg}$ body weight of rats. On the 15 th and 22 nd days at 10 a.m., all rats were treated based on experimental design. All rats in each group were blood drawn on the 28th day and stated as a post-treatment blood. At the end of treatment, the selected rats were sacrificed for histopathological investigation. The treatment for each group was performed for 14 days.

\section{Histopathological studies}

Histopathological studies of samples were executed on the kidney, pancreas, and liver organs of sacrificed rats. Histopathological examinations were performed on organs that had been immersed in formalin $10 \%$ in a week [29]. Organ slices were stained with hematoxylin eosin, and observations of cell performances in the kidneys, pancreas, and liver of rats were carried out using the Olympus DP12 microscope.

\section{Statistical analysis}

Experimental data on blood glucose levels were analyzed with two-way ANOVA using GraphPad Prism 8.1.2 software (GraphPad Software, Inc., San Diego, California, USA), and histopathological data were processed with SAS 9.1.3 Software (SAS Institute Inc.), Cary, North Carolina, USA).

\section{Results}

\section{Extraction and phytochemical screening}

The ethanolic extract of the Malaka flesh was separated by using the n-hexane, the dichloromethane and the ethyl acetate solvents. The separation process was done using the n-hexane solvent first, subsequently used a semi-polar solvents which were the dichloromethane and the ethyl acetate to attract semi-polar compounds [30]. The rendement data of the n-hexane, the dichloromethane, and the ethyl acetate fractions of the Malaka flesh were presented in Table 1 . It shows that the data of 
Table 1 Profile fraction of the Malaka flesh extracts on quantitative and qualitative records

\begin{tabular}{|c|c|c|c|c|c|c|c|c|c|}
\hline \multirow[t]{2}{*}{ No. } & \multirow[t]{2}{*}{ Fraction } & \multirow{2}{*}{$\begin{array}{l}\text { Weight } \\
\text { (g) }\end{array}$} & \multirow{2}{*}{$\begin{array}{l}\text { Rendement } \\
\text { (\%) }\end{array}$} & \multicolumn{6}{|c|}{ Secondary metabolite screening test } \\
\hline & & & & tri & alk & sap & $\tan$ & fla & phe \\
\hline 1 & n-Hexane & 7.50 & 18.75 & - & - & - & - & - & - \\
\hline 2 & Dichloromethane & 11.80 & 29.50 & - & - & - & + & ++ & ++ \\
\hline 3 & Ethyl acetate & 18.50 & 46.25 & - & - & + & ++ & +++ & +++ \\
\hline
\end{tabular}

Note: tri $=$ triterpenoids, alk $=$ alkaloids, sap $=$ saponins, $\tan =$ tannins, fla $=$ flavonoids, phe $=$ phenols, $-=$ negative result, $+=$ mild positive result, $++=$ moderate positive result, $+++=$ strong positive result

the separation of the Malaka flesh extract was more soluble in the semi-polar solvent. The fractions were performed by a phytochemical test. The results of this test can be seen in Table 1 .

\section{Total phenolic content and antioxidant property}

The total phenolic content (TPC) measured using the Folin-Ciocalte reagent showed a weight of $625.07 \pm 3.49$ (Means \pm SEM) mg Gallic Acid Equivalent (GAE) in the extract weight. The fraction of the ethyl acetate of the Malaka flesh obtained from the separation result was antioxidant activity test by using a DPPH method as a detector. The ascorbic acid (vitamin $\mathrm{C}$ ) was used as a positive control. The positive control was functioned to compare the natural antioxidant power of the ethyl acetate fraction. The absorbance of the sample extract is directly proportional to the percent of inhibition. The comparative results of the absorbance and the percent of inhibition of the ethyl acetate fraction of the Malaka flesh and the vitamin $C$ were displayed in Fig. 1 . The obtained \% value of inhibition can be used to determine the value of $\mathrm{IC}_{50}$. The $\mathrm{IC}_{50}$ values obtained from the vitamin $\mathrm{C}$ and the ethyl acetate fraction of the Malaka flesh are 6.34 and $7.20 \mathrm{ppm}$ respectively.

\section{In vivo toxicity assay}

The data obtained from the test of blood glucose level in rats were studied by a two-way ANOVA analysis with 0.05 confidence level. Results of data analysis of blood glucose level can be seen in Table 2. The two-way examination was piloted on the stimulus of the ethyl acetate extract of the Malaka flesh on blood glucose level in diabetic-induced rats.

\section{Histopathological studies}

Histology observations in the kidney, pancreas and liver of the rats showed encouraging results as presented in Table 3. All observed images showed the repair of cells that were previously damaged due to diabetes mellitus became normal after being given the ethyl acetate extract from the Malaka flesh.

\section{Discussion}

The data in Table 1 inform the $\mathrm{n}$-hexane fraction showed negative results of the triterpenoid, alkaloid, saponin,

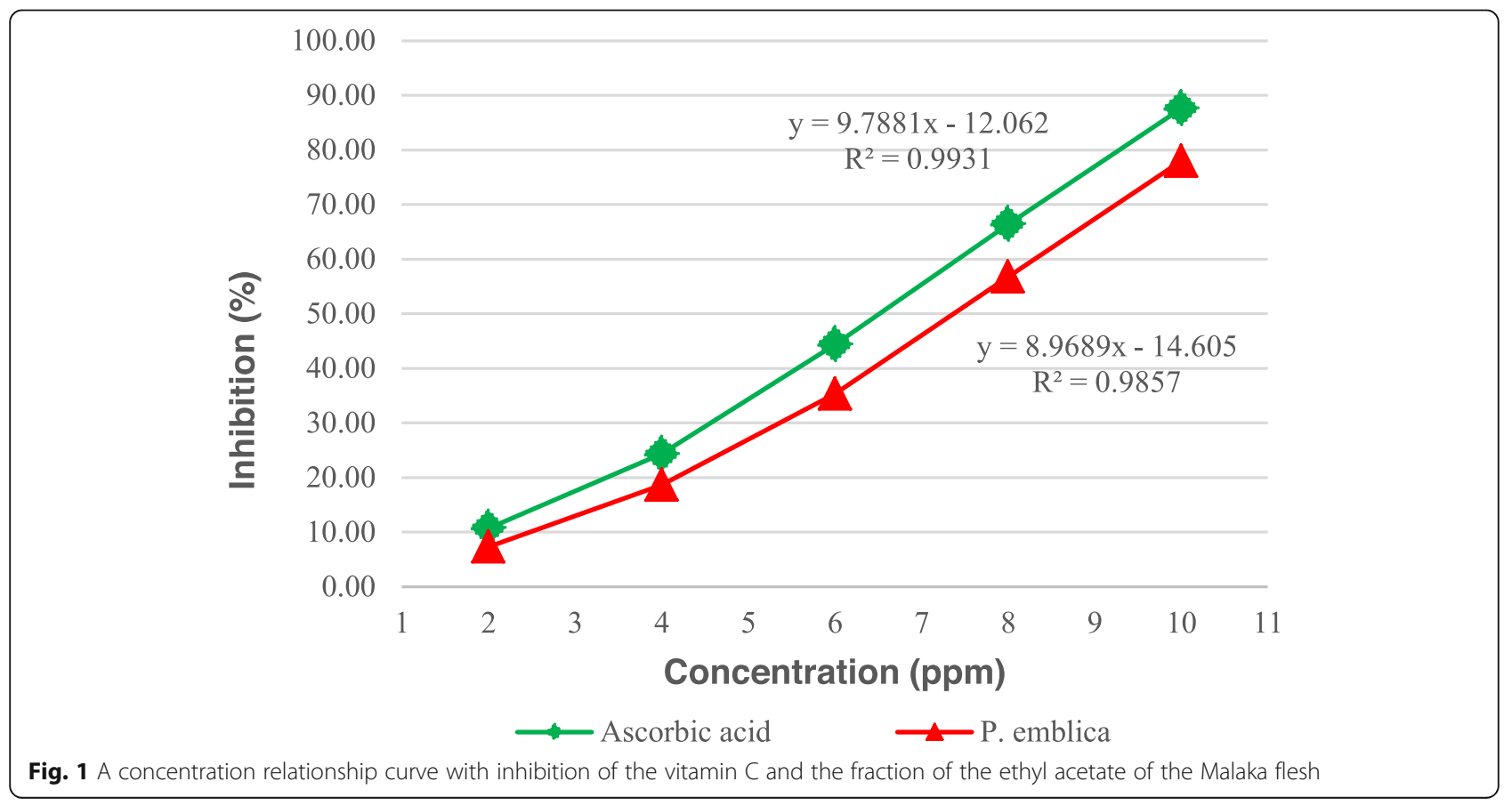


Table 2 Effect of the phenolic extract of the P. emblica flesh on the blood glucose level of the glucose induced rats

\begin{tabular}{|c|c|c|c|c|}
\hline \multirow[t]{2}{*}{ No. } & \multirow[t]{2}{*}{ Treatment } & \multicolumn{3}{|c|}{ Level of Blood Glucose (Mean \pm SD, mg/dL) } \\
\hline & & Pre-treatment blood & Diabetic blood & Post-treatment blood \\
\hline \multirow[t]{4}{*}{1} & P0 & $97.33 \pm 0.58$ & $387.33 \pm 9.02$ & $399.00 \pm 1.73^{\mathrm{a}}$ \\
\hline & P1 & $97.67 \pm 0.58$ & $381.33 \pm 6.11$ & $98.67 \pm 1.15^{\mathrm{b}}$ \\
\hline & P2 & $98.00 \pm 1.73$ & $384.00 \pm 3.61$ & $104.00 \pm 6.93^{b}$ \\
\hline & P3 & $97.67 \pm 0.47$ & $388.00 \pm 0.82$ & $119.00 \pm 0.82^{c}$ \\
\hline \multirow[t]{4}{*}{2} & ANOVA table & $\mathrm{F}(\mathrm{DFn}, \mathrm{DFd})$ & $p$ value & \\
\hline & Interaction & $F(6,16)=1369$ & $<0.0001$ & \\
\hline & Concentration (extract and control) & $F(3,8)=1313$ & $<0.0001$ & \\
\hline & Blood Glucose Level & $F(1.69,13.49)=17,012$ & $<0.0001$ & \\
\hline \multirow[t]{4}{*}{3} & Dunnett's post hoc test & $p$ value & Significant? & \\
\hline & P0 versus P1 & $<0.0001$ & Yes & \\
\hline & $P 1$ versus $P 2$ & $=0.5403$ & No & \\
\hline & $\mathrm{P} 1$ versus $\mathrm{P3}$ & $<0.0001$ & Yes & \\
\hline
\end{tabular}

Different letters designated significant differences among the group $(p<0.05$, Dunnett's post hoc following the two factor ANOVA), P0 $=$ the negative control, $\mathrm{P} 1=$ the positive control, $\mathrm{P} 2=$ the ethyl acetate extract of the Malaka flesh given a concentration of $100 \mathrm{mg} / \mathrm{kg}$ body weight, P3 = the ethyl acetate extract of the Malaka flesh given a concentration of $200 \mathrm{mg} / \mathrm{kg}$ body weight

tannin, flavonoid, and phenol components. An evaluation for triterpenoid and alkaloid components confirmed negative results on all fractions. Saponins test performed positive results on the ethyl acetate fraction characterized by foam-shaped as high as one cm after being shuffled vertically. The fractions of the dichloromethane and the ethyl acetate showed positive result to the tannins test with the formation of white precipitate. The flavonoids test showed a positive result on the fractions of the dichloromethane and the ethyl acetate with the formation of a faded yellow solution. The flavonoid test can be done with alkaline reagent test that dissolved the extract with $\mathrm{NaOH} 0.1 \mathrm{M}$ and then added of dilute acid. Colors that change from a dark yellow to a faded yellow show positive flavonoids [31]. In the phenol test, the $\mathrm{FeCl}_{3} 1 \mathrm{M}$ solution was used to determine whether the extract contained phenolic compounds. Samples containing the phenolic compounds are characterized by the formation of a blackish blue/blackish green solution. In the phenol test, the dichloromethane and the ethyl acetate fractions showed positive results in the formation of a blackish blue solution. The phenolic compounds tend to dissolve in polar solvents [32]. Referring to the profile data in Table 1, the most interested fraction to pharmaceutical evaluation of anti type 2 Diabetes mellitus was the semi-polar fraction of the ethyl acetate with a weight fraction obtained $18.50 \mathrm{~g}$.

The DPPH (2,2-diphenyl-1-picrylhydrazyl) is a compound in the form of free radicals [33]. The free radical DPPHs may react with existing antioxidants in the Malaka flesh extract. The DPPH has unpaired electron that tends to receive free electron from antioxidants in the sample extract. An antioxidant from the Malaka flesh extract can donate a hydrogen atom so the DPPH will be reduced. The deep violet color of the DPPH solution when mixed with the ethyl acetate fraction of the Malaka flesh extract changed to pale yellow. The absorbance of the DPPH decreased due to the DPPH captured free radicals from the ethyl acetate fraction of the Malaka flesh. Determination of antioxidant sample to DPPH test should be measured its absorbance at $517 \mathrm{~nm}$

Table 3 A number of cells on histology of kidney, pancreas, and liver rats in various treatments

\begin{tabular}{llllll}
\hline Treatment & Histology of rat kidney & & $\begin{array}{l}\text { Histology of rat } \\
\text { pancreas }\end{array}$ & & Histology of rat liver \\
\cline { 2 - 3 } & $\begin{array}{l}\text { Normal cells of renal tubules } \\
\text { (cells, Mean } \pm \text { SD) }\end{array}$ & $\begin{array}{l}\text { Proximal renal necrosa } \\
\text { tubules (cells, Mean } \pm \text { SD) }\end{array}$ & $\begin{array}{l}\text { Pancreatic } \beta \text { cells } \\
\text { (cells, Mean } \pm \text { SD) }\end{array}$ & $\begin{array}{l}\text { Normal hepatocyte count } \\
\text { (cell, Mean } \pm \text { SD) }\end{array}$ & $\begin{array}{l}\text { Necrosa hepatocytes } \\
\text { (cells, Mean } \pm \text { SD) }\end{array}$ \\
\hline P0 & $560 \pm 10,00^{\mathrm{a}}$ & $32 \pm 2,08^{\mathrm{d}}$ & $450 \pm 10,00^{\mathrm{a}}$ & $180 \pm 10,00^{\mathrm{a}}$ & $13 \pm 3,51^{\mathrm{c}}$ \\
P1 & $435 \pm 13,22^{\mathrm{c}}$ & $123 \pm 4,72^{\mathrm{a}}$ & $420 \pm 10,00^{\mathrm{b}}$ & $140 \pm 10,00^{\mathrm{b}}$ & $30 \pm 7,63^{\mathrm{ab}}$ \\
P2 & $447 \pm 11,50^{\mathrm{c}}$ & $103 \pm 10,06^{\mathrm{b}}$ & $410 \pm 11,53^{\mathrm{b}}$ & $123 \pm 9,50^{\mathrm{b}}$ & $43 \pm 10,14^{\mathrm{a}}$ \\
P3 & $534 \pm 10,00^{\mathrm{b}}$ & $76 \pm 9,50^{\mathrm{c}}$ & $436 \pm 15,82^{\mathrm{ab}}$ & $164 \pm 12,50^{\mathrm{a}}$ & $25 \pm 5,00^{\mathrm{bc}}$ \\
\hline P0
\end{tabular}

$\mathrm{P} 0=$ the negative control, $\mathrm{P} 1=$ the positive control, $\mathrm{P} 2=$ the ethyl acetate extract of the Malaka flesh given a concentration of $100 \mathrm{mg} / \mathrm{kg}$ body weight, $\mathrm{P} 3=$ the ethyl acetate extract of the Malaka flesh given a concentration of $200 \mathrm{mg} / \mathrm{kg}$ body weight. Different letters showed significant differences among the group $(p<0.05)$ 
wavelength by using a spectrophotometer [34]. Calculation results based on experimental data showed that the vitamin $\mathrm{C}$ and the ethyl acetate fraction from the Malaka flesh gained $\mathrm{IC}_{50}$ values of 6.34 and $7.20 \mathrm{ppm}$ respectively. The ethyl acetate fraction consisted of phenolics, flavonoids, tannins, and saponins. The phenolic components have demonstrated a number of biological effects such as antioxidant activity through mechanisms as reducing agents, free radical catchers, metal chelating, reducing the formation of singlet oxygen and electron donors [35]. The high antioxidant activity was indicated by the smallest $\mathrm{IC}_{50}$ value. Antioxidant activity is directly proportional to total phenol [36], the higher the phenol content in the ethyl acetate fraction $(625.07 \pm 3.49 \mathrm{mg}$ GAE) the higher its activity as an antioxidant $\left(\mathrm{IC}_{50}\right.$ value of $7.20 \mathrm{ppm}$ ). This finding showed an optimistic affinity between the radical scavenging action and the total phenolic content [37].

The ethyl acetate fraction of the Malaka flesh could decrease blood glucose level in the rats after given 50\% glucose monohydrate solution due to it has phenolic contents as shown in Fig. 2. The flavonoid substances are secondary metabolite compounds had an antioxidant property that can capture free radicals [38]. Reducing free radicals can prevent damage to pancreatic $\beta$ cells and cause sufficient quantities of insulin to reduce blood glucose levels [39]. The blood glucose level experimental data analyzed by two-way ANOVA showed that the interaction effect was significant, $F(6,16)=1366$, $p<0.0001$. The main effect for concentration of the extract and the control generated an $\mathrm{F}$ ratio of $\mathrm{F}(3,8)=$
1313, $p<0.0001$, demonstrating a significant difference of the blood glucose level in the post-treatment among the negative control (Mean $=399.00, \mathrm{SD}=1.73$ ), the positive control (Mean $=98.67, \mathrm{SD}=1.15)$, the concentration of $100 \mathrm{mg} / \mathrm{kg}$ body weight $($ Mean $=104.00, \mathrm{SD}=$ 6.93), and the concentration of $200 \mathrm{mg} / \mathrm{kg}$ body weight $($ Mean $=119.00, \mathrm{SD}=0.82)$. The main effect for the blood glucose level produced an $F$ ratio of $F(1.69$, 13.49) $=17,012, p<0.0001$, representing that the effect for the blood glucose level was significant. The Dunnet's post hoc analysis showed the administration of the extract to the experimental rats at a concentration of $100 \mathrm{mg} / \mathrm{kg}$ body weight had the same effect on the decrease in blood glucose shown by administering the metformin $(p=0.5403)$. Whereas, administration of the extract at a concentration of $200 \mathrm{mg} / \mathrm{kg}$ body weight showed a significantly different $(\mathrm{p}<0.0001)$ effect with the metformin administration. This could be understood that the administration of the extract with a dose of $100 \mathrm{mg} / \mathrm{kg}$ body weight in the diabeticinduced rats could reduce blood sugar levels better than administering the extract at a dose of $200 \mathrm{mg} / \mathrm{kg}$ body weight compared to the effect of giving the metformin as a blood sugar-reducing drug.

The histopathological observations in kidney cells showed changes in the proximal tubule of the kidney as displayed in Table 3. Changes occurred in the tubule damage cells or necrosa. The number of necrosa cells in the group given the control treatment of the drug metformin was the same as the treatment of the ethyl acetate fraction of the Malaka flesh on a

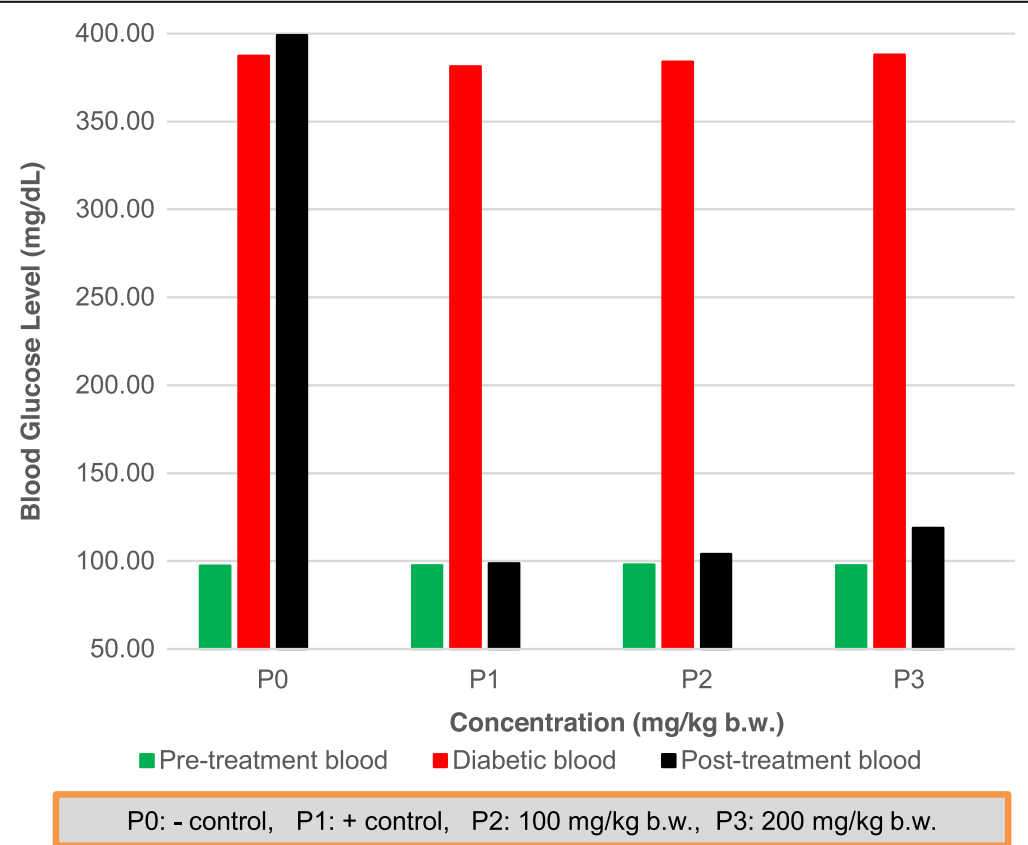

Fig. 2 Diagram of the treatment relationship of each group with blood glucose level 

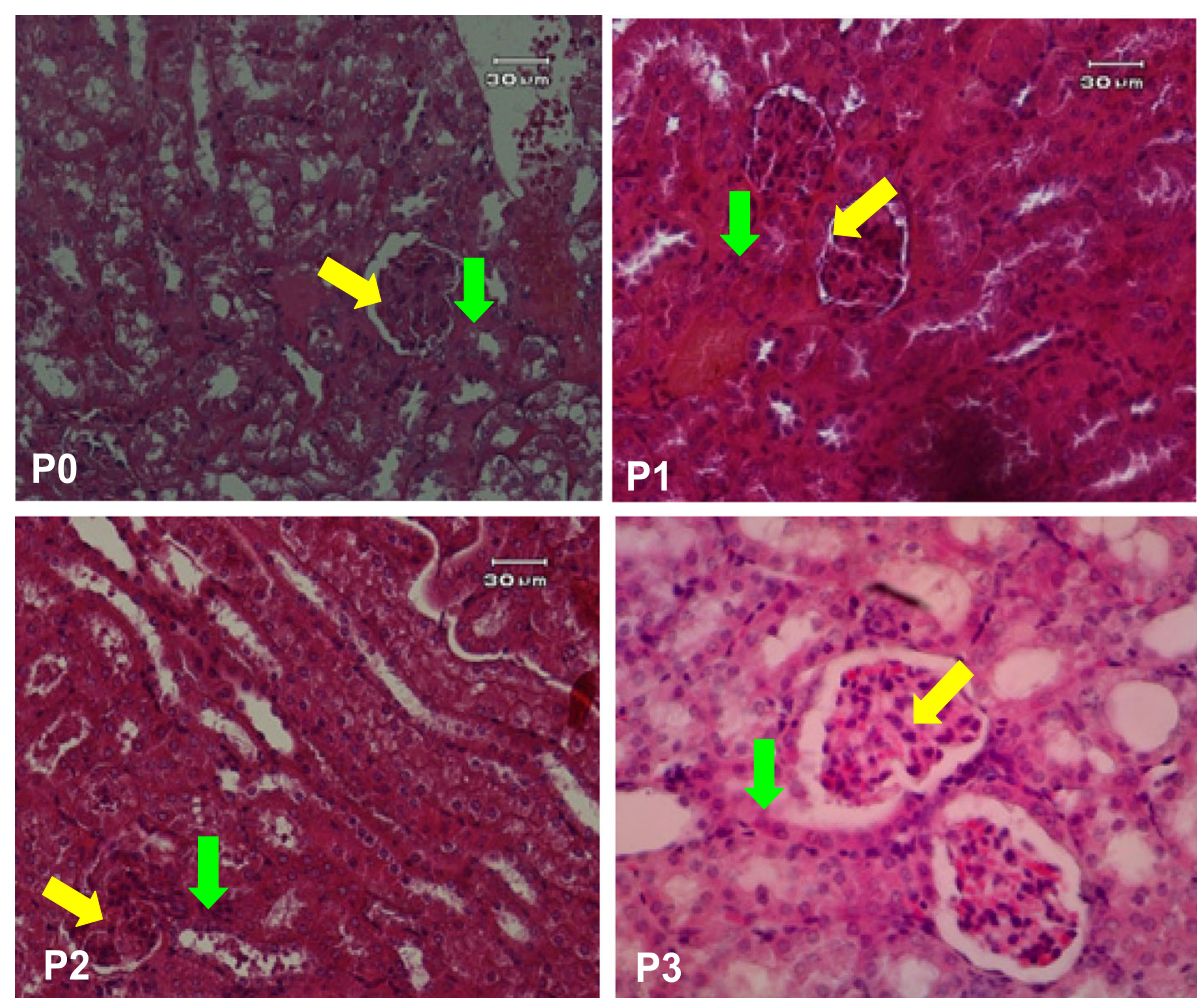

Fig. 3 Renal histology in the rats given the ethyl acetate fraction of the Malaka flesh. Yellow arrow= Glomerulus, green arrow = proximal tubule
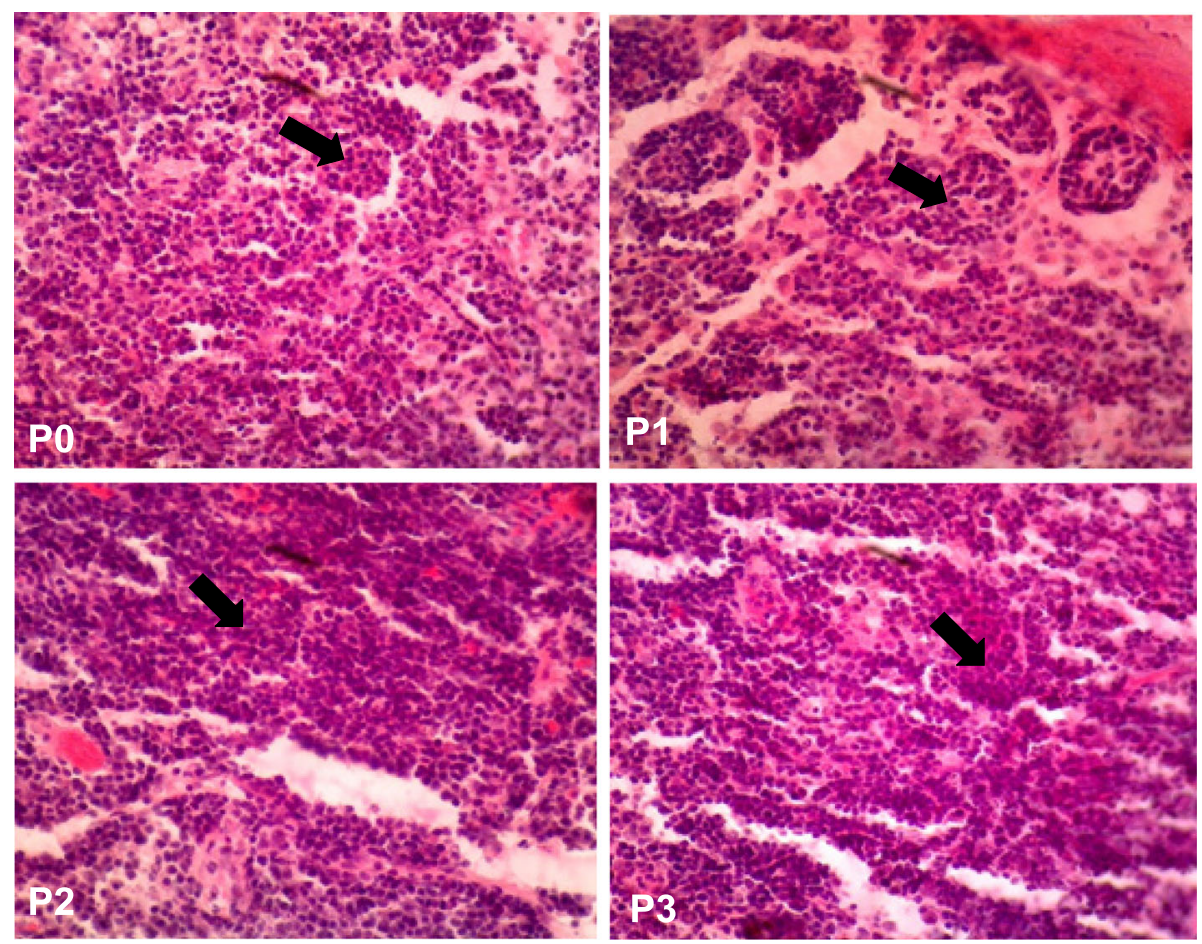

Fig. 4 Pancreatic histology in the rats given the ethyl acetate fraction of the Malaka flesh. Black arrow= pancreatic beta cell 

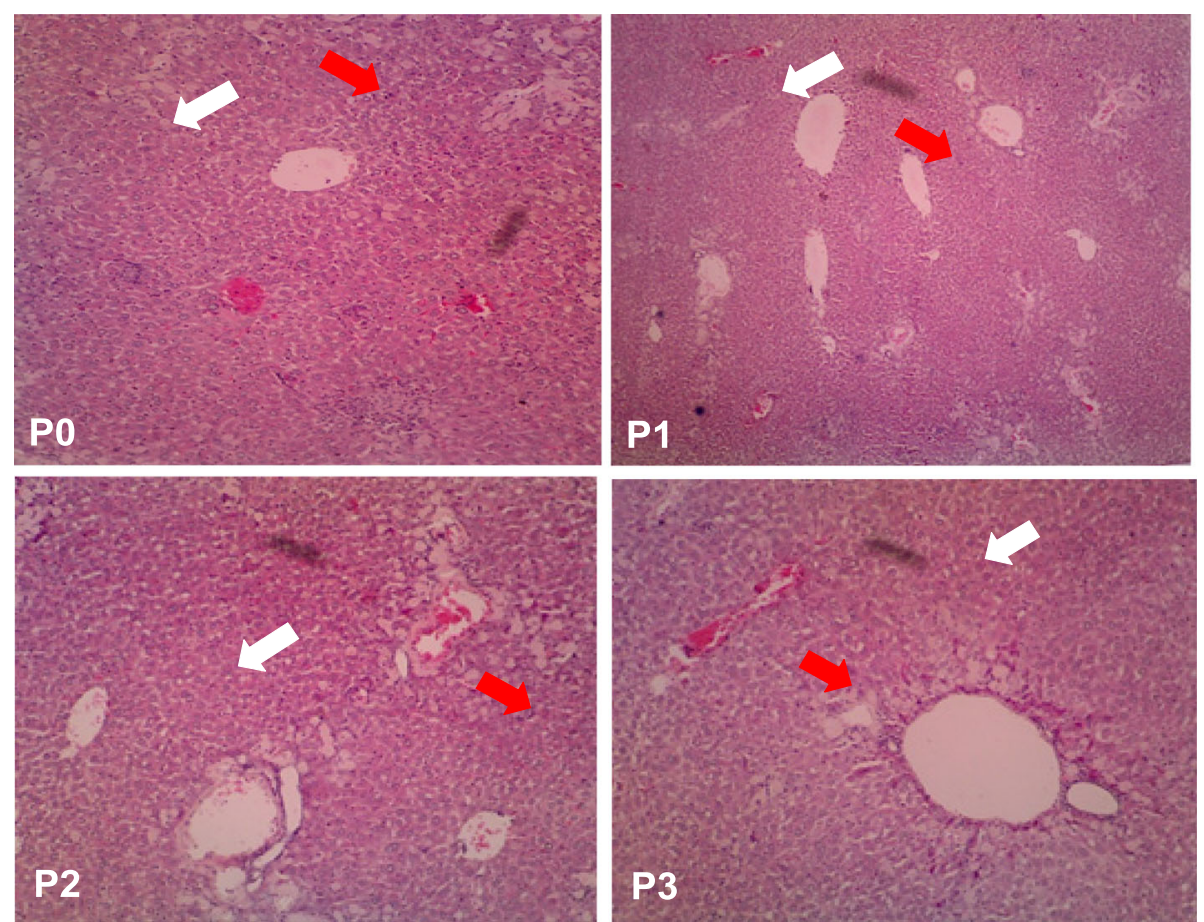

Fig. 5 Histology description of liver in the rats given the ethyl acetate fraction of the Malaka flesh. White arrow = hepatocyte, red arrow = necrosa

concentration of $100 \mathrm{mg} / \mathrm{kg}$ body weight. Administration of the metformin can decrease hyperglycemia so that it can minimize kidney tubular cell impairment. The results showed that administration of the ethyl acetate fraction of the Malaka flesh at a concentration of $200 \mathrm{mg} / \mathrm{kg}$ body weight demonstrated specific destruction to renal tubular cell in the diabetic rats. The kidneys are the target organs of insulin. The insulin cascade in the glomerulus indicates a disturbance [40]. In diabetes circumstances, stimulus of insulin in the proximal tubular transport of the kidneys is disrupted, therefore, glucose absorbed declines and is secreted through urine [41, 42]. The administration of the ethyl acetate fraction of the Malaka flesh improved the renal and cells in the proximal tubule were identical to normal rats as evidenced in Fig. 3.

The quantity of pancreatic $\beta$ cells in the tested rat showed the same amount found in normal rat $(p<0.05)$ as shown in Table 3 . The pancreatic $\beta$ cells secrete insulin, insulin functions to control glucose levels in the blood to normal, so that hyperglycemic conditions can be overcome [43]. The antioxidant substances found in the Malaka flesh can overcome hyperglycemic conditions by improving pancreatic $\beta$ cell regeneration as shown in Fig. 4.

The administration of the ethyl acetate fraction did not damage the liver cells (hepatocytes), i.e. the number of hepatocytes under normal conditions as revealed in Table 3 and proven in Fig. 5. The number of necrosis in liver cells given the ethyl acetate fraction at a concentration of $200 \mathrm{mg} / \mathrm{kg}$ body weight was the same as the number of normal rat liver cells $(p<0.05)$. The liver cells experienced necrosa were in the normal threshold, meaning that the antioxidant components found in the ethyl acetate fraction of the Malaka flesh could repair liver cells and not caused toxic to the rat liver cells. Antioxidant induced morphological changes in hepatocytes of both the normal and the diabetic rats [44].

\section{Conclusions}

The conclusions of this study are:

1) The ethyl acetate fraction of Malaka flesh with a concentration of $100 \mathrm{mg} / \mathrm{kg}$ body weight could reduce blood sugar levels equivalent to the administration of metformin with a concentration of $65 \mathrm{mg} / \mathrm{kg}$ body weight.

2) The administration of the ethyl acetate fraction of Malaka flesh was able to repair damaged cells and restore their function as demonstrated in the histology of the kidney, pancreas, and liver in the tested rats.

\section{Acknowledgements}

The authors express thanks to the staffs of the Chemistry Laboratory of the Teacher Training and Education Faculty and the Pharmacological Laboratory of the Veterinary Faculty of Syiah Kuala University for their generous assistances. 


\section{Author details}

'Department of Chemistry Education, Teacher Training and Education Faculty, Syiah Kuala University, Darussalam-Banda Aceh 23,111, Indonesia. ${ }^{2}$ Department of Biology Education, Teacher Training and Education Faculty, Syiah Kuala University, Darussalam-Banda Aceh 23,111, Indonesia.

\section{Declarations}

All authors read the manuscript and approved it for submission. No part of the manuscript has been published before, nor is any part of it under consideration for publication at another journal.

\section{Authors' contributions}

Author MM planned the work, the literature search, the data analysis, and writing of the manuscript. Author MZ performed the practical work. Author RFIR and EE supervised the work and participated in the literature search. Author SS took part in the data analysis. The authors read and agreed the final manuscript.

\section{Funding}

The study was run with the financial support received from Syiah Kuala University with contract grant number: 66/UN11.2/PP/SP3/2018.

\section{Availability of data and materials}

The data produced or evaluated during the study are incorporated in this publication article.

\section{Ethics approval}

The procedures for the use of laboratory animals were administered after obtaining approval from the Veteriner Ethics Committee for Animal Trial of Faculty of Animal Medicine of Syiah Kuala University (Ref.: 2011a/UN11.1.22/ TU/2017).

\section{Consent for publication}

Not applicable.

\section{Competing interests}

The authors declare that they have no competing interests.

\section{Author details}

${ }^{1}$ Department of Chemistry Education, Teacher Training and Education Faculty, Syiah Kuala University, Darussalam-Banda, Aceh 23111, Indonesia. ${ }^{2}$ Department of Biology Education, Teacher Training and Education Faculty, Syiah Kuala University, Darussalam-Banda, Indonesia.

\section{Received: 22 August 2019 Accepted: 11 December 2019} Published online: 23 December 2019

\section{References}

1. World Health Organization. About diabetes. Diabetes Programme; 2019. https://www.who.int/diabetes/action_online/basics/en/index3.html

2. Stöppler MC. Normal Blood Sugar Levels (Ranges) In Adults with Diabetes. San Clemente, California; MedicineNet. Inc.; 2019. https://www.medicinenet. com/normalbloodsugarlevelsin...withdiabetes/article.html.

3. Huizen J. "What are the ideal blood sugar levels?" Medical News Today. Medilexicon, Intl., 17 May 2019. Web. 20 Jul. 2019. https://www. medicalnewstoday.com/articles/317536.php

4. Karuranga S, Fernandes JDR, Huang Y, Malanda B, editors. IDF diabetes atlas. 8th ed. Belgium: International Diabetes Federation; 2017. https://www.idf. org/e-library/epidemiology-research/diabetes-atlas/134-idf-diabetes-atlas8th-edition.htm

5. Hasyim (Ed.). 500,000 Acehnese Diabetes. Banda Aceh; Serambi Indonesia; 2017. https://aceh.tribunnews.com/2017/04/17/500000-warga-aceh-diabetes.

6. Huri HZ, Lim LP, Lim SK. Glycemic control and antidiabetic drug in type 2 diabetes mellitus patients with renal complications. Drug Design Dev. Therapy. 2015;9:4355-71. https://doi.org/10.2147/DDDT.S85676.

7. Ketz J. A Review of Oral Antidiabetic Agents. Pharmacotherapy Update Newsletter. 2001;IV(3): May/June.

8. American Diabetes Association. Standards of medical care in diabetes-2018. Diabetes Care. 2018;41(suppl 1):S31-59.

9. Gupta RC, Chang D, Nammi S, Bensoussan A, Bilinski K, Roufogalis BD. Interactions between antidiabetic drugs and herbs: an overview of mechanisms of action and clinical implications. Diabetol. Metabolic Syndrome. 2017;9:59-70. https://doi.org/10.1186/s13098-017-0254-9.

10. Li WL, Zheng HC, Bukuru J, De Kimpe N. Natural medicines used in the traditional Chinese medical system for therapy of diabetes mellitus: review. J Ethnopharmacol. 2004;92:1-21.

11. Choudhury H, Pandey M, Hua CK, Mun CS, Jing JK, Kong L, Ern LY, Ashraf NA, Kit SW, Yee TS, Pichika MR, Gorain B, Kesharwani P. An update on natural compounds in the remedy of diabetes mellitus: a systematic review. J Tradit Complement Med. 2018;8:361-76. https://doi.org/10.1016/j.jtcme. 2017.08.012.

12. Jain PK, Das D, Pandey N, Jain P. Traditional Indian herb Emblica Officinalis and its medicinal importance. Innov J Ayruvedic Sci. 2016;4(4):1-15.

13. Ho CT, Lee CY, Huang MT. Phenolic compounds in food. In Phenolic Compounds in Food and their Effects on Health, Vol. I. Analysis, Occurrence \& Chemistry. Washington, DC: ACS Symposium series 506; 1992.

14. Chen J, Mangelinckx S, Adams A, Wang ZT, Li WL, De Kimpe N. Natural flavonoids as potential herbal medication for the treatment of diabetes mellitus and its complications. Nat Prod Commun. 2015;10(1):187-200.

15. Chi CL, Shu HY, Shih MH, Chi HW, Gow CY. Inhibitory effects of Phyllanthus emblica L. on hepatic Steatosis and liver fibrosis in vitro. J Funct Foods. 2016;20:20-30.

16. Bashir A, Mushtaq A, Mehboob T. Evaluation of antioxidant and Antidiabetic activity of Phyllanthus emblica (fruit). Biologia Pakistan. 2018;64(1):85-91.

17. Asgar MA. Anti-diabetic potential of phenolic compounds: a review. Int J Food Prop. 2013;16:91-103. https://doi.org/10.1080/10942912.2011.595864.

18. Ahangarpour A, Sayahi M, Sayahi M. The antidiabetic and antioxidant properties of some phenolic phytochemicals: a review study. Diab Metabolic Syndr Clin Res Rev. 2019;13:854-7. https://doi.org/10.1016/j.dsx. 2018.11.051.

19. Pria FF, Islam MS. Phyllanthus emblica Linn. (Amla) - A Natural Gift to Humans: An Overview. J Dis Med Plants. 2019;5(1):1-9. https://doi.org/10. 11648/j.jdmp.20190501.11.

20. Kolhe SS, Rachh PR. Review of potent antidiabetic plants or herbs from traditional medicine. J Drug Deliv Therap. 2018;8(5):92-8. https://doi.org/10. 22270/jddt.v8i5.1856

21. Khoo HE, Azlan A, Kong KW, Ismail A. Phytochemicals and Medicinal Properties of Indigenous Tropical Fruits with Potential for Commercial Development. Evidence-Based Complementary and Alternative Medicine. 2016; Article ID 7591951, 20 pp. https://doi.org/10.1155/2016/7591951

22. Krishnaveni M, Sankaran M, Kandan K, Ganesan D. Antidiabetic and Antihyperlipidemic properties of Phyllanthus emblica Linn. (Euphorbiaceae) on Streptozotocin induced diabetic rats. Pak J Nutr. 2010;9(1):43-51.

23. Sultana Z, Jami MSI, Ali ME, Begum MM, Haque MM. Investigation of Antidiabetic effect of Ethanolic extract of Phyllanthus emblica Linn. Fruits in experimental animal models. Pharmacol Pharm. 2014;5:11-8. https://doi.org/ 10.4236/pp.2014.51003.

24. Chaudhuri A, Sharma S. Evaluation of Antidiabetic Activity of Polyherbal Formulation in Streptozotocin-Induced Diabetic Rats. UK J Pharm Biosci. 2016:4(5):1-6. https://doi.org/10.20510/ukjpb/4/i5/113983

25. Tiwari P, Kumar B, Kaur M, Kaur G, Kaur H. Phytochemical screening and extraction: a review. Internationale Pharmaceutica Sciencia. 2011; 1(1):98-106

26. Siddiqui N, Rauf A, Latif A, Mahmood Z. Spectrophotometric determination of the total phenolic content, spectral and fluorescence study of the herbal Unani drug Gul-e-Zoofa (Nepeta bracteata Benth). J Taibah Univ Med Sci. 2017;12(4):360-3.

27. Molyneux $\mathrm{P}$. The use of the stable free radical Diphenylpicrylhydrazyl (DPPH) for estimating antioxidant activity. Songklanakarin J Sci Technol. 2004;26(2):211-9.

28. Alexandru I. Experimental use of animal in research spa. Balneo Res. J. 2011; 2:65-9. https://doi.org/10.12680/balneo.2011.1014

29. Spitalnik PF. Histology laboratory manual 2016-2017. College of Physicians and Surgeons.: New York: Columbia University; 2016.

30. Marcelinda A, Ahmad R. Prismawiryanti. Antioxidant activity of extract of Ari coffee bean skin waste (Coffea sp.) based on solvent polarity level. J Nat Sci. 2016:5(1):21-30.

31. Alves DR, de Morais SM, Tomiotto-Pellissier F, Miranda-Sapla MM, Vasconcelos FR, da Silva ING, de Sousa HA, Assolini JP, Conchon-Costa I, Pavanelli WR, da Chagas Oliviera Freire F. Flavonoid Compositiion and Biological Activities of Ethanol Extracts of Cryocar coriaceum Wittm., a Native Plant from Caatinga Biome. Evidence-Based Complementary and 
Alternative Medicine 2017; Article ID 6834218: 7 pp. https://doi.org/10.1155/ 2017/6834218

32. Barbar N, Oberol HS, Sandhu SK, Bhargav VK. Influence of different solvents in extraction of phenolic compounds from vegetable residues and their evaluation as natural sources of antioxidants. J Food Sci Technol. 2014; 51(10):2568-75. https://doi.org/10.1007/s13197-012-0754-4.

33. Shimamura T, Sumikara Y, Yamazaki T, Tada A, Kashiwagi T, Ishikawa H, Matsui T, Sugimoto N, Akiyama H, Ukeda H. Applicability of the DPPH assay for evaluating the antioxidant capacity of food additives - inter-laboratory evaluation study. Anal Sci. 2014;30:717-21.

34. Kedare SB, Singh RP. Genesis and development of DPPH method at antioxidant assay. J Food Sci Technol. 2011;48(4):412-22. https://doi.org/10. 1007/s13197-011-0251-1.

35. Karadeniz F, Burdurlu HS, Koca N, Soyer Y. Antioxidant activity of selected fruits and vegetables grown in Turkey. Turk J Agric For. 2005;29:297-303.

36. Huang D, Ou B, Prior RL. The chemistry behind antioxidant capacity assays. J Agric Food Chem. 2005;53(6):1841-56. https://doi.org/10.1021/jf030723c

37. Genwali GR, Acharya PP, Rajbhandari M. Isolation of Gallic acid and estimation of total phenolic content in some medicinal plants and their antioxidant activity. Nepal J Sci Technol. 2013;14(1):95-102.

38. Kaempe SH, Edi S, Shirley ESK. Potential of phenolic extract of Goroho Banana fruit (Musa spp.) on blood sugar of white rat (Rattus norvegicus). Chem Prog. 2013;6(1):6-9.

39. Cerf ME. Beta cell dysfunction and insulin resistance. Frontiers in Endocrinology 2013; 4: Article 37, 12 pp. https://doi.org/10.3389/fendo. 2013.000.37

40. Lay A, Coward RJ. Recent advances in our understanding of insulin signalling to the podocyte. Nephrol Dial Transplant. 2014;29:1127-33. https://doi.org/10.1093/ndt/gft471.

41. Horita S, Nakamura M, Suzuki M, Satoh N, Suzuki A, Homma Y, Nangaku M The role of renal proximal tubule transport in the regulation of blood pressure. Kidney Res Clin Pract. 2017;36(1):12-21. https://doi.org/10.23876/j. krcp.2017.36.1.12.

42. Vallon V, Thomson SC. Targeting renal glucose reabsorption to treat hyperglycaemia: the pleiotropic effects of SGLT2 inhibition. Diabetologia. 2017;60(2):215-25. https://doi.org/10.1007/s00125-016-4157-3.

43. Zheng S, Zhao M, Wu Y, Wang Z, Ren Y. Suppression of pancreatic beta cell apoptosis by Danzhi Jiangtang capsule contributes to the attenuation of type 1 diabetes in rats. BMC Complement Altern Med. 2016;16:31. https:// doi.org/10.1186/s12906-016-0993-4

44. Li S, Tan HY, Wang N, Zhang ZJ, Lao L, Wong CW, Feng Y. The role of oxidative stress and antioxidants in liver diseases. Int J Mol Sci. 2015;16: 26087-124. https://doi.org/10.3390/ijms161125942.

\section{Publisher's Note}

Springer Nature remains neutral with regard to jurisdictional claims in published maps and institutional affiliations.

\section{Submit your manuscript to a SpringerOpen ${ }^{\circ}$ journal and benefit from:}

- Convenient online submission

- Rigorous peer review

- Open access: articles freely available online

High visibility within the field

- Retaining the copyright to your article

Submit your next manuscript at $\boldsymbol{\nabla}$ springeropen.com 